\title{
NOVA FASE DA ECONOMIA MUNDIAL E A CRISE DO EURO: a China, a Europa e a América ${ }^{1}$
}

\author{
Robert Rollinat
}

\begin{abstract}
Aborda-se, aqui, as causas profundas da crise e as formas que ela tomou durante os últimos cinco anos, particularmente sobre a gigantesca concorrência, verdadeira "guerra de moedas". Para além da "crônica de acontecimentos" da crise - suas dimensões financeira e monetária, crise das dívidas "soberanas", o futuro e a "sobrevida" do euro - busca-se a problemática que circunscreve esta crise desde 2008. O fio condutor, capaz de abarcar seu processo, continua sendo aquele da análise do processo real, baseado no método e na teoria de Marx, através da evolução do capitalismo de "concorrência". Revela-se a importância da concorrência e o fato de que, atualmente, ela também tende a se exacerbar. Evidenciam-se as novas condições de valorização do capital e a busca pelo lucro, em processos complexos de destruição-criação de valor e se ilustram, também, os mecanismos ligados à superacumulação do capital, à superprodução de mercadorias dela decorrentes. Marx nos ajuda a compreender que, para sobreviver, o capitalismo deve continuar "extorquindo" a mais-valia, a qualquer preço. É um imperativo absoluto para sua reprodução e o que hoje lhe confere um caráter predador e brutal em todos os domínios da vida social.

Palavras-Chave: Capital. Trabalho. Finanças. Destruição de valores. Crise mundial.
\end{abstract}

\section{INTRODUÇÃO}

Há mais ou menos cinco anos, o mundo tem sofrido as consequências da deflagração da crise capitalista. Em diferentes regiões do planeta, ela se reproduz com graus diferentes e com nuances que, no entanto, não eliminam de modo algum as manifestações de suas causas mais profundas, que estão ligadas, inevitavelmente, à lógica da reprodução do capital e às formas de apropriação das mais-valias.

Depois da deflagração da crise de outono de 2008, tendo como ponto de partida a falência do banco Lehman Brothers nos Estados Unidos, a questão que se deve levantar hoje é mesmo: como chegamos a este ponto? O fim do ano de 2008 foi marcado pela explosão brutal de uma crise bancária e financeira excepcional. Nascida nos Estados Unidos com os subprimes (créditos imobiliários subscritos por famílias desde então insolventes), esta crise se espalhou, como um rastro de pólvora,

* Doutor em História Econômica. Professor aposentado da Universidade de Paris X. rrollinat@wanadoo.fr

${ }^{1}$ Tradução de George Mascarenhas. Revisão técnica, Jorge Nóvoa. por todo o planeta. Daí, as manifestações financeiras da crise revelaram, rapidamente, suas origens econômicas, industriais e sociais: superprodução de mercadorias, programas inteiros de moradia e escritórios invendáveis, explosão do fechamento de empresas e demissões em todos os setores de atividade. Os economistas concordam em considerar que o pior está por vir.

O que está em questão é a própria natureza do capitalismo e de um sistema de acumulação predatória, fundado sobre a busca exclusiva do lucro e da especulação. Não se trata de simples desvios ou de faltas éticas que poderiam ser resolvidos por meio de novas regras do jogo ou normas reguladoras: é a própria lógica dos mercados mundializados, que se desenvolveram sem controle há vários decênios, que é questionada. Esta situação histórica excepcional convoca, imediatamente, a comparação com a grande crise dos anos 1930, que conduziu ao fascismo e à guerra. É necessário, desde já, tentar compreender o seu desenrolar, pois ela já condiciona a vida cotidiana de milhares de homens e mulheres, em todos os países do mundo. 
Nos últimos tempos, o discurso econômico e político dos adeptos fanáticos do mercado livre e da mundialização sem barreiras modificou-se um pouco. Em contradição total com os preceitos anteriormente anunciados e considerados como incontornáveis, exige-se do Estado, ou seja, dos cidadãos, que venham em socorro dos bancos e dos capitães de indústria em dificuldade. É preciso avaliar o significado destas tentativas no contexto de uma compreensão global do conjunto do sistema e das relações de classes subjacentes. Deste ponto de vista, as análises e os conceitos herdados da teoria de Marx, suas explicações sobre as crises industriais e bancárias do século XIX, sobre as crises de superprodução, conservam, não apenas toda sua pertinência, mas constituem-se, hoje, na única referência teórica que permite compreender os acontecimentos.

Sem sombra de dúvida, um novo período histórico se abriu. Será um período caótico, marcado por numerosos conflitos, com consequências políticas e sociais incalculáveis. Convém, para além dos fatos em si e da explosão midiática das "más-notícias", tentar compreender as origens e as causas desta crise, o que está em jogo e suas consequências para o futuro.

Lembremos que, no início de 2011, um grande número de economistas e especialistas tinha considerado que o pior da crise já tinha passado e que a "retomada", embora lenta e difícil, estava doravante assegurada. Outros tinham estimado que os novos países emergentes (dentre os quais a China) constituíam, a partir de então, as locomotivas da economia mundial e que seu forte crescimento, notadamente em termos de Produto Interno Bruto e de superávit de exportação, permitiriam uma retomada progressiva do comércio e da produção. Algumas projeções quantitativas previam uma retomada em duplo mergulho (double dip): uma primeira recuperação dos indicadores de produção seria seguida por uma recaída, antes de uma saída definitiva do aperto. O problema é que, se nos situarmos em um nível macroeconômico global, esta primeira recuperação não aconteceu e a grave crise financeira e monetária e os eventos do outono de 2011 ainda nos afastam por mais tempo desta perspectiva.

De fato, a crise atual, como toda crise do modo de produção capitalista, deve ser antes considerada como uma crise de valorização do capital. ${ }^{2}$ Para "realisar" o valor, não é somente necessário extrair o lucro para remunerar os investidores e aportadores de capital, mas, também, assegurar a reprodução do capital investido. Como assegurar isso em um mundo onde o crescimento econômico tende, cada vez mais, a zero em vários países, ou em várias regiões? Será que a China poderá salvar o capitalismo?

\section{A CONCORRÊNCIA MUNDIAL E OEURO}

Para ilustrar concretamente os mecanismos gerais da concorrência no contexto do capitalismo mundializado, podemos, simplesmente, no nível europeu, relembrar alguns elementos da crônica financeira do outono de 2011. Na terça-feira, 13 de setembro de 2011, enquanto as Bolsas europeias continuavam degringolando e as taxas de juros das obrigações do estado italiano decolavam, a China reafirmava "sua confiança na economia europeia e no euro", ao tempo em que engajava discussões, por intermédio do fundo soberano China Investment Corp., a favor do resgate de uma parte da dívida "soberana" da Itália. Com efeito, segundo um economista chinês autorizado, citado pela A.F.P., para a China, "as obrigações italianas poderiam revelarse bons negócios" e a China "deveria ver se pode tirar vantagem desta oportunidade (a crise da dívida) para abrir um caminho em suas relações e cooperação com os países europeus, como a Itália e a França”. Para a China, o "auxílio" à Europa seria uma oportunidade para diversificar a distribuição de suas reservas de câmbio (2,3 trilhões de euros), quase que exclusivamente orientadas para as obri-

${ }^{2}$ Para lembrar a explicação geral das crises em Marx, remetemos a nosso texto: La crise du capitalisme d'aujourd'hui: une analyse marxiste. Ver a revista O Olho da História n.14, Salvador (Ba), junho 2010, http:/ /oolhodahistoria.org/n14/mundourgente.php. Ver Harman Chris (2010), particularmente, os três primeiros capítulos, p. 21 à 85 . 
gações de estado americanas, mas, também, (de acordo com o China Daily, citado por Le Monde, de 15 de setembro), de realizar, nestes tempos de crise "fusões e aquisições na zona do euro, mais particularmente para as empresas de alta tecnologia".

Finalmente, neste mesmo 13 de setembro, as discussões entre a delegação do fundo soberano chinês e a Itália fracassaram, acentuando, no mesmo dia, a queda das Bolsas na Europa e em Wall Street, mas o episódio é revelador da amplitude da crise do euro e da impotência política e financeira dos países credores obrigados a "salvar" a Grécia da falência. Se, evidentemente, os chineses pudessem se responsabilizar por uma parte da dívida italiana (mais de 1,9 trilhões de euros), com uma dimensão totalmente diferente daquela de Portugal ou da Grécia, os "mercados" e, sobretudo, os bancos credores em dificuldade muito grande (notadamente os franceses e alemães) teriam se desafogado na mesma proporção. Talvez a dívida soberana italiana não tivesse sido degradada por Standard \& Poor's, uma semana depois, com um endividamento atual equivalente a $120 \%$ do seu Produto Interno Bruto. A Itália, terceira economia da União Monetária e, segundo um especialista, o mais importante "porta corta-fogo" da França, está diretamente ameaçada por uma crise de liquidez dos seus bancos e não estará em condições, por razões sociais e políticas evidentes, de colocar em prática os planos de austeridade preconizados pelo Banco Central Europeu. Restará, então, recorrer a um "fundo de resgate" da zona do euro, ainda no limbo, e do qual a Itália deveria ser, justamente, um dos principais contribuintes.

Nãoé, portanto, catastrofismo considerar que o conjunto do sistema de bancos europeus está agora ameaçado. A impotência das diferentes cúpulas e reuniões de crise para simplesmente estabilizar (senão resolver) a situação, revela a profunda desordem política dos responsáveis por uma Europa econômica "virtual”, construção institucional e jurídica artificial, colocada a serviço dos partidários da mundialização e dos dirigentes do capital internacional. Que o primeiro ministro chinês Wen Jiabao se diga hoje "pronto para ajudar os europeus" se derem prova "de mais responsabilidade e se colocarem ordem em suas casas", não é, simplesmente, uma presunção vexatória; isso testemunha a evolução da crise mundial desde 2008: novas relações de força políticas e econômicas, uma nova configuração geopolítica mundial progressivamente ganharam espaço, no qual, incontestavelmente, a "velha Europa", mas também os Estados Unidos, tem seu lugar diretamente contestado no plano internacional.

A aceleração da crise aberta da zona do euro, iniciada em agosto de 2011, pode ser considerada, também, como uma nova fase da rivalidade entre o euro e o dólar. ${ }^{3}$ Alguns analistas acreditaram ver nisso um "complô" dos anglo-saxões contra a moeda europeia. Segundo o "eurocético" Financial Times de Londres, financiadores em Wall Street e na "City" teriam sido suspeitos de participar dos ataques contra o Euro, a fim de colocar os bancos europeus (e franceses em particular) em dificuldades, facilitando, assim, o seu resgate por bancos americanos (tese retomada na França por Laurence Parisot, responsável pelo MEDEF). De fato, não havia nenhuma necessidade de organizar um complô para que os especuladores, notadamente aqueles ligados aos hedge funds, fundos de investimento de risco, decidissem "jogar para baixo" a dívida grega para concretizar seus ganhos. O que efetivamente aconteceu no início de setembro.

Também é evidente que os Estados Unidos (país superendividado e que tem, portanto, necessidade de que outros países, notadamente a China, comprem uma parte de sua enorme dívida) devem hoje fazer com que o dólar continue sendo, para além de suas dificuldades, a moeda de referência internacional e, portanto, têm todo interesse em "desacreditar" o euro. Apesar disso, a falência de um estado europeu teria hoje enormes consequências para a economia mundial. É por esta razão que Timothy Geithner, secretário do Tesouro Americano e artesão dos "planos de retomada" do presidente Obama veio, no dia 16 de se-

${ }^{3}$ Ver nosso texto anterior: La guerre des monnaies: une nouvelle étape de la crise capitaliste?, http:// www.preavis.org/breche-numerique/article2438.html, março 2011. 
tembro, para a reunião do Eurogrupo na Polônia para incitar os europeus a "agir de modo decisivo e ter uma só voz”. A “divisão” dos europeus impõe um "risco catastrófico para a economia mundial”, estimou, considerando que o crescimento europeu "poderia estar virtualmente parado no fim do ano". Mas o presidente do Eurogrupo respondeu, ao longo desta mesma reunião, que não havia mais, na zona do euro, "nenhuma margem de manobra para lançar um novo plano de suporte à economia”.

Com efeito, os mecanismos ditos keynesianos, de retomada, ${ }^{4}$ de fato, sobretudo até a presente criação maciça de moedas na impressora de dinheiro (a "monetização” das dívidas), apenas adiaram os prazos, sem permitir a retomada dos investimentos. Eles contribuíram, apenas, para o aumento descontrolado do endividamento dos Estados. Desde então inoperantes, eles demandam uma nova "purgação” do sistema, na qual, desta vez, será mesmo necessário tentar saldar as contas. É por esta razão que os bancos europeus, retraídos com altas taxas pelos Estados, depois de 2008, e que, para aumentar seus lucros, tinham em seguida emprestado em massa a países insolventes, estariam agora limitados a "sacrificar" uma parte dos seus créditos recebíveis afim de serem rapidamente recapitalizados.

\section{OS BANCOS, SUAS FALÊNCIAS E SUA RECAPITALIZAÇÃO: um novo 2008?}

Atualmente, segundo dados recentes, os bancos da União monetária seriam dotados de 32,5 trilhões de euros de ativos, dos quais uma parte em créditos podres ou tóxicos. Este montante re-

${ }^{4}$ De fato, os monetaristas à la Friedman consideravam igualmente que os Estados, via Banco Central, deviam, em períodos de crise, permitir o crescimento da massa monetária e de depósitos bancários. Em um texto célebre, Friedman estimava que, se em 1929, a Federal Reserv tivesse agido desse modo, a crise poderia ter sido evitada nos Estados Unidos. A divergência com os "verdadeiros" keynesianos é centrada, de fato, sobre o volume da criação ex-nihilo de moeda. É assim que Paul Krugman (em suas crônicas no New York Times), mas também Martin Wolf (no Financial Times de Londres, substituído pelo Le Monde) não pararam, desde 2009, de criticar a "timidez" dos planos de retomada americanos e, sobretudo, a incapacidade de os governos europeus seguirem a mesma via. presenta 350\% do PIB desta mesma zona do euro (nos Estados Unidos, esta mesma proporção é de aproximadamente 80\%). Isso confirma o fato de que, para os bancos europeus (e o capital financeiro no qual eles se apoiam), o crédito constitui, no período de 2008-2010, um elemento muito importante, apesar de perfeitamente artificial e perverso, de valorização do capital.

Esses bancos, não somente subscreveram em massa os empréstimos de Estado emitidos pelos Estados soberanos do Sul e do Leste europeu, não só eles “acompanharam” os projetos de investimento não-rentáveis (as estradas portuguesas e os novos aeroportos espanhóis hoje não explorados são um bom exemplo), como, também, assumiram participações e, até diretamente, o controle de bancos nestes mesmos Estados. Estes bancos (na maioria dos casos filiais de grandes grupos bancários europeus) não tinham condição de impulsionar uma atividade produtiva rentável, portanto de "reembolsar" os adiantamentos em capital consentidos. São estes três elementos juntos que constituem hoje as bases do endividamento considerável das principais redes de banco europeus.

Mas é o contexto europeu do euro, "moeda única”, e também os fundos europeus, que foram o veículo da política “monetária” do Banco Central Europeu, que podem fornecer, com taxas muito baixas, aos bancos credores, o crédito necessário a estas diversas operações. Estes bancos emprestadores extraíram, durante um tempo, lucros substanciais, já que eles mesmos emprestavam com uma taxa muito mais alta. A falta de pagamento da Grécia foi o revelador de um superendividamento que encontra sua fonte, ao mesmo tempo, na instância da desregulação financeira e na isca do ganho dos banqueiros. ${ }^{5}$

Hoje em dia, não se trata somente de os bancos tentarem recuperar seus investimentos em créditos recebíveis na Grécia, país quase insolvente, mas, também, com montantes ainda maiores, na Itália, na Espanha (cujas notas de dívidas sobe-

${ }^{5}$ Esta dimensão "gananciosa” do Banco, às vezes difícil de entender para os não iniciados, foi, para os Estados Unidos, bem analisada por Madrick, 2011. 
ranas foram de novo rebaixadas desde outubro de 2011), mas, também, em Portugal e outros países do Leste Europeu. Enquanto, há apenas alguns meses antes, no período em causa, esses bancos tinham sido objeto de "testes" de resistência positivos ("stress" tests), eles agora revelam, brutalmente, a insuficiência de seus fundos próprios, sua subcapitalização. Amontoados com títulos de divida soberana, fortemente desvalorizados (negociáveis, às vezes, a menos da metade do seu valor de emissão), eles, mais uma vez, convocam os Estados, em primeiro lugar a dupla franco-alemã, supostamente os que podem garantir a estabilidade na zona do euro.

Na França, a falência do Banco DEXIA veio confirmar a dificuldade da situação. O DEXIA é o exemplo-tipo destes bancos que tinham "prosperado" com a crise, na França, a partir, essencialmente, de atividades "de mercado" e da subscrição de dívidas “soberanas”. ${ }^{6}$ A falência do DEXIA anuncia outras falências bancárias na Europa.

Doravante, a crise "política" nos Estados Unidos, na Alemanha, na França e em todos os países endividados interfere, diretamente, sobre a crise financeira e social. Nenhuma medida parcial pode resolver os problemas de fundo. Todas as medidas financeiras tomadas atualmente ressaltam a urgência, destinando-se a evitar o golpe, o mais rapidamente possível, sem, verdadeiramente, "tranquilizar os mercados”, ou seja, o capital e a finança especulativa. ${ }^{7}$

${ }^{6}$ O Banco Dexia, já “salvo” em 2008 (com 6 bilhões de euros) pela França e Bélgica, era especializado, na França, em empréstimos às coletividades locais. Privatizado e entrando na lógica dos "bancos de mercado", estava no final do verão de 2011, "chumbado" por 95 bilhões de euros de ativos "tóxicos", dos quais não pode se deslastrar, mas também estava fortemente engajado nas dívidas gregas, espanhola e italiana. Depois da cessão de ativos ainda "rentáveis" (a filial turca Denizbank e o setor de "banco privado") foram, outra vez, os Estados belga e francês que foram chamados em seu socorro para liquidar as perdas. Na França, a carteira de empréstimos às coletividades locais, avaliada em 70 bilhões de euros, seria retomada pela Caisse des Depôts e pelo Banque Postale. Uma vez mais, socialização das perdas depois da privatização dos ganhos. Em abril de 2011, o PDG recebeu 600.000 euros de bônus, a título do exercício de 2010.

${ }^{7}$ Assim, no dia 16 de setembro de 2011, dia após dia, três anos depois da falência do Lehman Brothers, os bancos centrais (FED, BCE, Banco da Inglaterra, Banco do Japão) decidiram-se por uma “ação coordenada” para for-
O Fundo Europeu de Estabilização Financeira - FESF, laboriosamente estabelecido há alguns meses, não dispõe de meios suficientes para recapitalizá-los (ou seja, aumentar seus fundos próprios). Os bancos mais expostos às dividas soberanas dos países em perigo como a Grécia ou a Itália (mas também a Espanha, cuja dívida foi de novo aprofundada em meados de outubro) estão, portanto, agora diretamente ameaçados de falência, com todas as consequências sociais e políticas que podem ser decorrentes. Em um mês, suas cotações na Bolsa despencaram ${ }^{8}$ e sua capitalização bolsista reduziu brutalmente. Recapitalizar-se consistiria, para eles, em dirigir-se aos “mercados", a seus acionistas (notadamente, a seus dirigentes que se beneficiaram largamente dos "bônus") para aumentar o nível dos fundos próprios e até para solicitar "compradores" estrangeiros. Mas quem aceitaria engajar-se agora em operações tão arriscadas? Então, o último recurso da Finança, diante da ameaça de uma falência bancária generalizada, a partir de então, são os Estados.

Foi exatamente isso o que aconteceu, ainda no dia 27 de outubro de 2011, em Bruxelas, ao cabo de uma semana agitada de negociações e de uma nova cúpula voluntariamente dramatizada.

necer, de maneira ilimitada, dólares a todos os estabelecimentos financeiros europeus. O Banco Central Europeu decidiu, por sua vez, fornecer "com guichê aberto" e, momentaneamente sem limite, a liquidez demandada pelos bancos. Assegurar em regime de urgência a "liquidez" do sistema é evitar a aderência completa de financiamentos bancários, notadamente aqueles do comércio internacional (o dólar sendo ainda a principal divisa de câmbio nos mercados de matérias-primas).

${ }^{8}$ Os bancos franceses foram os mais atacados na Bolsa. $O$ índice Euro Stox de ações bancárias europeias perdeu $46 \%$ entre 7 de julho e 12 de setembro de 2011 . Entre $1^{\circ}$ de julho e 12 de setembro, a capitalização da bolsa do BNP Paribas diminuiu em 52\%, a do Societé General em $60 \%$, a do Crédit Agricole em quase 55\% (média dos bancos europeus: queda de 33\% nos três últimos meses do período em causa). Em dois meses, mais de 69 bilhões de euros se volatizaram para os três bancos franceses. Note-se que, três meses antes, estes bancos foram bem sucedidos nos stress tests (indicadores de solvência) e Madame Parisot afirmou recentemente: "os bancos franceses são os mais sólidos do mundo". No final de setembro os fundos americanos tinham, em três meses, reduzido em mais de um quarto seus investimentos nos bancos europeus. Os bancos europeus foram outra vez muito atingidos na Bolsa no fim de outubro, depois da "desvalorização" dos títulos gregos. Primeiro o banco italiano UNICREDIT anunciou, no dia 15 de novembro de 2011 , uma perda histórica de 10,5 bilhões de euros. Sua capitalização na bolsa caiu de 43 para 14,5 bilhóes de euros entre abril de 2010 e outubro de 2011, depois da depreciação de suas filiais na Europa Oriental. 
Para “salvar” a Grécia, foi necessário consentir-lhe uma ajuda suplementar de 30 bilhões de euros e, sobretudo, os bancos emprestadores foram, desta vez, obrigados a aceitar uma desvalorização de 50\% dos seus títulos para aquele país, “apagando”, assim, uma parte de sua dívida pública.

Este abandono de créditos, considerado como "voluntário" não conduzirá aos mecanismos clássicos de "segurança” (notadamente os célebres CDS: Credit Default Swaps) que, supostamente, devem proteger os credores da falência de um devedor. O endividamento da Grécia com o FMI e o Banco Central Europeu não será reduzido em um dólar sequer.

Mas qual será a contrapartida deste auxílio? Que a Grécia siga os planos de autoridade em curso e acelere as privatizações para chegar a quinze bilhões de euros. Estas medidas deveriam, então, com o horizonte de 2020 (!), trazer o endividamento da Grécia de $160 \%$ a $120 \%$ de seu Produto Interno Bruto, permitindo-lhe, então, voltar "aos mercados". ${ }^{9}$ De fato, tudo isso suporia uma retomada da economia grega (em "crescimento negativo" desde 2008) e um salto de suas exportações (somente 7\% do PIB, dentre os quais o turismo e o armamento marítimo, a taxa mais baixa da zona do euro) e também entradas fiscais oriundas de atividades econômicas rentáveis. Os recentes desenvolvimentos da situação neste país não caminham nesta direção.

O futuro continua muito problemático na

${ }^{9}$ Durante todo este tempo, a especulação continuou. A "finança da sombra" e, notadamente, os hedge funds, que tinham inicialmente "jogado" os bancos franceses para baixo, com sucesso, em setembro, puderam comprar, com vantagem, a divida grega (40 bilhões de euros desde o fim de julho, segundo uma estimativa da City de Londres). Mesmo desvalorizados em 50\%, estes títulos de dívida poderiam ainda ser muito rentáveis para seus detentores. garantias revela, imediatamente, seus limites, se considerarmos que os principais contribuintes deste fundo (em $2^{\mathrm{a}}, 3^{\mathrm{a}}, 4^{\mathrm{a}}$ posições, respectivamente: a França, a Itália e a Espanha) poderiam, em um futuro próximo, ser levados a solicitar sua ajuda.

Então, quem poderia, doravante, neste caos político-financeiro, "salvar" o euro participando do "fundo de resgate" europeu e da recapitalização dos bancos credores de países em déficit? Os países ditos emergentes foram solicitados a oferecer sua "ajuda". Dentre eles, a China vem em primeira linha. Já tendo subscrito obrigações emitidas pela FESF, ela ainda poderia aportar de 35 a 70 bilhões de euros. A condição: aceder rapidamente ao "estatuto de economia de mercado" da Organização Mundial do Comércio, ou seja, permitir que suas mercadorias (e seus investimentos) tenham acesso mais livre nos países europeus. A China, a maior economia do mundo com superávit de exportação, portanto com reservas consideráveis, seria, financeiramente, a melhor colocada para ajudar a Europa. Ela exigirá, no entanto, garantias sólidas para subscrever as dívidas soberanas da zona do euro, bem como o acesso a esses mercados. Por outro lado, para conquistar suas exportações e afirmar sua influência na Europa, ela tem todo interesse em "salvar" a zona do euro, impedindo, se possível, que ela entre em uma nova fase de depressão.

Esses conflitos "de hegemonia" não decorrem diretamente de mecanismos gerais da concorrência, mas estão ligados a eles. Eles revelam, sobretudo, o lugar tomado pelos recém-chegados nas trocas mundiais. Com a interdependência mundial crescente, a "prescão" chinesa poderia, segundo alguns, favore er un a maior integração do capital no nível europu e, para outros, contribuir ainda mais para a ra ra as rivalidades comerciais no próprio seio d $\mathrm{z}$ nn do euro. ${ }^{10}$

O cenário due pa ece mais provável, na aurora de 2012, é me sn o quele das novas falências ${ }^{10} \mathrm{E}$ por isso que é pr cis $\mathrm{b}$ t ntar medir o impacto da onda recente de investim ent ps hineses na Europa. Na Grécia, a gigante chinesa $\mathrm{d}$ sso q er tornar o porto de Pireu sua porta de entrada n a Uni o Europeia (investimento de 3,4 bilhões de eur s). N(vos contratos estão previstos com a China que ir ves tiri nos serviços bancários, telecomunicações e mosmp n indústria de cerveja. Ela já é candidata à privati aç o o as estradas de ferro. 
ou fusões-reestruturações de bancos no próprio seio da zona do euro, como prevê o último relatório trimestral do próprio Banco Central Europeu. De acordo com este relatório, o indicador do "risco sistêmico", aquele que informa sobre a solidez da "rede bancária" em sua totalidade, nunca foi tão elevado, muito superior àquele que tinha predominado por ocasião da crise dos subprimes. As ações dos grandes bancos europeus, de fato, perderam quase dois terços do seu valor desde o início de 2011 e os contratos financeiros de "garantia" como os CDS, Credit Defaut Swaps, que deveriam fazer face às limitações dos Estados, das empresas, dos próprios bancos, correm o risco de ser inoperantes. A perda de confiança é tal que a falta de liquidez pode hoje derrubar um banco e, por contaminação, outros bancos, já que tudo se conjuga: a crise das dívidas soberanas, a fragilidade do sistema bancário e o marasmo crescente das economias. A crise de liquidez é tal que o BCE foi obrigado, em 20 de dezembro, a colocar, mais uma vez, à disposição dos bancos europeus, à "guichê aberto", perto de 500 bilhões de euros para evitar falência.

\section{CONCORRÊNCIAESUPERACUMULAÇÃO COMO CAUSAS DA CRISE DO CAPITALISMO}

Para repetir, aqui, de maneira muito geral e de um ponto de vista global, as dificuldades para o capital gerar lucros suficientes na esfera produti$v a$, por não encontrar, nos mercados mundiais, uma demanda solvente suficiente (em particular nos Estados Unidos), conduziram o sistema a buscar, por todos os meios, outros modos de valorização. Na esfera real, em razão de uma concorrência internacional aumentada, tendo visto restringiremse os investimentos rentáveis, geradores de lucros, a própria base da acumulação capitalista, outras oportunidades de ganho foram exploradas. Assim, no início dos anos 2000, a orientação do capitalismo em direção ao suporte constituído pela economia de rede pôde ser considerada como uma das manifestações mais espetaculares da dificuldade do capital em continuar sua valorização no setor real. Assistiremos, neste setor, à criação de uma bolha artificial de superinvestimento que engendrará uma sobreprodução de ofertas de serviços. A desconexão com relação às necessidades reais do mercado conduzirá ao crash desta economia de rede. Outras formas de valorização serão colocadas em prática, sobretudo pela deslocalização em direção a países "periféricos" com baixo custo de mão de obra.

Afirmando-se progressivamente, a partir dos anos 1980, a financeirização das economias consistiu, portanto, em buscar, na atividade bancária, na especulação financeira, oportunidades de lucro à margem da esfera real, diretamente produtora de mercadorias ou de serviços.

O crédito foi um dos principais veículos desta financeirização já que permitiu manter, por um tempo, certo nível de consumo, apesar dos ganhos salariais em baixa. Até o desencadeamento da crise iniciada no fim de 2008, os Estados Unidos foram o exemplo-tipo deste modelo de crédito e de especulação, modelo gerador do capital que podemos considerar como ficcional, já que não conduz a um verdadeiro acúmulo, sendo financiado com capitais que podem, a qualquer momento, escorrer para fora do sistema. O sistema de crédito foi levado ao extremo nos Estados Unidos onde, com a garantia do Estado, os bancos puderam subscrever, para famílias em parte insolventes, empréstimos imobiliários (os famosos empréstimos Ninja), para terem acesso à propriedade. Assim que a reviravolta do setor imobiliário se produziu, estes empréstimos subprime se tornaram irrecuperáveis e foram os bancos emprestadores e os organismos hipotecários que deram garantias que entraram em falência. Sabemos como, depois de 2008, esta crise se difundiu, através dos suportes titularizados de "empréstimos tóxicos", em inúmeros bancos no mundo inteiro.

Se, aparentemente, a crise dos subprimes nos Estados Unidos e a queda bolsista mundial decorrente foram, realmente, o elemento deflagrador da crise mundial, esta última só é compreensível, no entanto, em seus desenvolvimentos posteriores, se for considerada a longa sequência da evolu- 
ção da economia "real”. Se a mundialização das economias (preponderância do "mercado", liberalização "selvagem” dos câmbios, desregulação e regulação de instituições bancárias e de Bolsas, desregulamentação do mercado de trabalho) favoreceu a chegada da crise e, em seguida, permitiu sua difusão no mundo inteiro, é preciso, no entanto, para além desta constatação, considerá-la antes como uma crise do capitalismo de concorrência..$^{11}$ Por esta ótica, dizer que a crise atual é "sistêmica", velha amiga dos reformistas e "reguladores" de qualquer natureza, é pura tautologia. Isso consiste, muito frequentemente, em estigmatizar "os excessos" da finança, denunciar a cobiça pelo ganho e a inconsequência dos banqueiros, de quem se exige uma "nova distribuição de riquezas". São escamoteadas as bases materiais da crise do capital, seu modo de evolução e seu aprofundamento desde o crash bancário e financeiro do outono de 2008. A concorrência é inerente ao sistema. Ela supõe a "caça" permanente de lucros, de oportunidades de capitais disponíveis. É o "ferrão da concorrência" que puxa para baixo os lucros, tendo em conta a insuficiência da demanda solvente nos mercados. A "lei" de baixa tendencial das taxas de lucro surge, logicamente, desta análise.

A crise conduziu a uma baixa, sempre brutal, da atividade econômica e, portanto, do número de negócios das empresas. Na maior parte dos setores, elas se aproveitaram disso para racionalizar a produção: racionalização das estruturas, deslocamento de certas produções ou de empresas inteiras para países com baixo custo de mão de obra, demissões, desemprego parcial, baixa de salários quando a resistência dos assalariados era insuficiente. Não se trata, aqui, de analisar em detalhe as formas tomadas, nos diferentes países, por essas reestruturações, mas é evidente que seu objetivo, em um contexto de concorrência exacerbada pelo próprio desenrolar da crise, era a redução dos preços de produção de mercadorias e de serviços, para reduzir o preço nos mercados "globais"

${ }^{11}$ Harman, op.cit., p. 57-59, lembra sobre este aspecto as concepções de Marx sobre a própria “essência” do capitalismo e suas reflexões sobre a possibilidade/ inevitabilidade das crises. cada vez mais competitivos e mundializados. Um exemplo-tipo talvez seja mesmo o do setor automobilístico. O setor, nos Estados Unidos, foi salvo da falência pelo Estado e profundamente reestruturado com o fechamento de fábricas, demissões, fusões ou acordos com empresas europeias ou asiáticas. Em 10 anos, construtores e fabricantes de equipamentos suprimiram 640.000 empregos nos Estados Unidos. Desde 2009, a empresa General Motors (com a Ford doravante aliada à Volkswagen) sobreviveu, mas fechou quatorze fábricas e reempregou, para o automóvel elétrico, uma pequena parte dos demitidos, porém com salários duas vezes menores..$^{12} \mathrm{Na}$ França, a empresa Renault, ex-símbolo "nacional" do setor, criou um conglomerado que associa, a partir de então, a japonesa Nissan, a russa Avtovaz, a romena Dacia, a coreana Samsung e uma sociedade com a alemã Daimler. A partir disso, de quatro automóveis Renault, três são produzidos em países estrangeiros (Eslovênia, Turquia, Espanha, Coréia) para os mercados locais ou para reimportação. Em 2009, o Estado francês, que tinha ainda 15\% do capital da ex-RÉGIE, tinha "emprestado" 3 bilhões de euros (assim como para a Peugeot) a fim de facilitar uma "mutação" produtiva que até hoje não salvou os empregos em Flins, Sandouville ou Douai. Todavia, Carlos Ghosn, o presidente da Renault, continuou sendo o patrão mais bem pago da França em 2010. Igualmente ilustrativo é o caso da Peugeot-Citröen, grupo mundializado desde então. Eles anunciaram, em novembro de 2011, a supressão de mais de 4000 postos de trabalho na França. Outro exemplo é o do aço. O número 1 da siderurgia mundial, a ArcelorMittal, doravante indiana, tinha fechado em 2008-2009 a metade de suas fábricas no mundo. Desde então, ela tinha desenvolvido, no nível mundial, uma estratégia de fusões-aquisições, privilegiando os países emergentes e reduzindo em massa os efetivos no trabalho, com enormes supercapacidades industriais na Europa e nos Estados Unidos. É, a partir de então,

${ }^{12}$ Cf. A General Motors reinava, mas em uma Detroit
agonizante, conforme Le Figaro Economie, 14 março de 2011 
um ator global presente desde a extração de minerais até a comercialização de produtos siderúrgicos. Seu principal cliente, em 2011, foi a China, que consome $40 \%$ da produção mundial de aço. Na França, estão desaparecendo as últimas usinas de aço compradas pela Arcelor. Em outro domínio completamente diferente, de inovação recente, a "guerra" engajada pelas principais operadoras de telefonia móvel mundial, em matéria de comercialização de iPads e de novos iPhones é também exemplar.

Nos países industrializados do "centro", apareceu, em numerosas filiais, um excesso das capacidades de produção. Equipamentos, fábricas inteiras foram descartados, outros pararam de produzir. Uma recomposição do capital foi operacionalizada em escala mundial, não apenas nos "velhos" setores da atividade manufatureira (agora, aliás, tornados, nestes países, um setor limitado da produção global: 7\% do PIB nos Estados Unidos), mas, também, em todos os outros setores: aqueles da distribuição e do transporte, nas tecnologias da informação e da imprensa, em todas as atividades de serviço, do Banco e da Bolsa. A posição da China como oficina do mundo foi reforçada e outros países ditos emergentes como a Índia, o Brasil ou a África do Sul puderam, assim, durante um tempo, beneficiar-se das transferências de capital em busca de valorização.

Esta dimensão geopolítica da reestruturação desde 2008 de um capitalismo já largamente mundializado é um elemento essencial para compreender a situação atual. O que se traduziu, no campo, por "demissões coletivas", na Europa, na América e em outros lugares, foi acompanhado por mudanças importantes na estrutura financeira de numerosas empresas: tomadas de participação de bancos ou de fundos de pensão, fusões entre firmas, mudança de razão social depois de concentrações, fusões ou novas entradas na Bolsa. No dia seguinte da crise, em 2009, as operações sobre o capital das empresas (fusões, aquisições, OPA amigáveis ou hostis) desaceleraram-se, mas foram fortemente retomadas em seguida e reencontraram seu ritmo de antes da crise. Estas transformações, mais ou menos rápidas, segundo as resistências sociais encontradas, foram, às vezes, acompanhadas por "ajudas" financeiras dos Estados e dos bancos centrais, com o objetivo sempre desejado da redução do "custo dos fatores de produção" e, notadamente, do primeiro dentre eles: o trabalho.

Do ponto de vista da "sequência" da crise iniciada em 2008, a desaceleração brutal da economia revelou, na maioria dos "velhos" países industriais, importantes supercapacidades de produção (estatisticamente mensuráveis através da redução das "taxas de utilização das capacidades produtivas”). Em vários setores, a crise levou a tornar obsoleta uma parte do capital investido anteriormente. Este capital nunca terminará seu ciclo produtivo (em termos contábeis, nunca será amortizado). Este processo de desvalorização, bem descrito por Marx, levou a uma perda considerável de valor; de fato, a uma destruição do valor.

A “desvalorização" do capital é permanente, mas ela se acentua durante a crise. Ela se traduz por uma forma de superacumulação do capital: capital excessivamente acumulado com relação às potencialidades do mercado e, portanto, às possibilidades de lucros. Apesar disso, mesmo em tempos de crise, a busca insaciável pelo lucro e a necessidade de valorizar os capitais disponíveis não interrompem o processo de acumulação que se concentrará em novos setores considerados como portadores do futuro e, portanto, supostamente "rentáveis". Para as grandes empresas, doravante mundializadas, os mecanismos de mudança de localização já evocados favorecerão esta evolução.

A acumulação de crise se concentra, portanto, nos setores onde o capital ainda é suscetível de aportar valor e lucro. As formas anteriores de produção, às vezes constituídas por equipamentos (de patentes) ou edifícios recentes (ainda não amortizados) se encontram subitamente obsoletos, fora do circuito, perdendo todo o valor. Temos, assim, uma enorme "destruição" de capital acumulado segundo um mecanismo predatório bem analisado por Marx: "a barreira do capital, é o próprio capital”. Este caráter "autodestrutivo" do modo de produção capitalista, particularmente agudo 
durante a crise, foi ressaltado, senão analisado, por inúmeros economistas. É um fator determinante, que permite compreender a "dinâmica" e as especificidades da crise em curso, bem como suas consequências sobre a força do trabalho e os salários.

A superacumulação de capital supõe, implicitamente, a superprodução de mercadorias (e de serviços). Dentre os setores onde a superacumulação parece particularmente importante: o transporte e, em particular, o transporte marítimo. Diante de uma redução geral do comércio mundial (menos 8\% entre o início de 2010 e o início de 2011), enormes supercapacidades de transporte marítimo apareceram (mineradores, petroleiros, portacontêineres). A frota de transporte de bens pesados é utilizada, hoje em dia, em apenas um terço de suas capacidades, levando-se em conta a entrega de novos barcos encomendados antes da crise. Os custos de transporte despencaram, ameaçando a sobrevivência das maiores companhias. Supercapacidades do mesmo tipo existem também no transporte aéreo de cargas e no transporte rodoviário. Ao lado dos setores industriais ou de serviço, é preciso também considerar o imobiliário. Depois da bolha especulativa neste setor, milhões de habitações, programas inteiros, nos Estados Unidos, na Espanha, na Irlanda tornaram-se invendáveis e permanecem atéhoje. O mesmo aconteceu no setor imobiliário comercial, no qual importantes supercapacidades surgiram. Trata-se, em consequência, de uma forma visível e incontestável de "destruição" de capital.

Esta superprodução é somente o subproduto da lei da concorrência, da "guerra econômica" que acontece entre os detentores dos capitais. A superprodução não se produz, necessariamente, pelos estoques físicos de bens não vendidos (embora este aspecto esteja evidentemente sempre presente). Doravante, graças a uma política "racional" de gestão da produção, fluxos de importação ou de exportação, a "superprodução" é apenas latente. De todo modo, ela será apenas relativa, em um mundo no qual as necessidades essenciais de uma parte importante da população não são supridas.
Ela só pode ser relativa, pois permanece limitada pelas capacidades de absorção do mercado e condicionada pela existência de uma demanda solvente que dependerá, essencialmente, com relação ao ciclo de produção, da parte da mais valia sobre a força de trabalho, da "partilha" entre os lucros e os salários. Que a posição política e social do assalariado tenha, nesta "partilha" um papel determinante é evidente.

De 2008 até hoje, a valorização do capital continuou, mas em condições cada vez mais difíceis e predatórias. Os grandes grupos mundializados foram, evidentemente, os melhores colocados para tirar lucro de uma situação na qual a base da extorsão da mais-valia é restrita, notadamente nos países do "centro". Os grandes grupos foram organizados em torno de certos setores-chaves da economia, sempre os mais rentáveis. Assim, na França, os lucros das sociedades do CAC 40, (o resultado líquido), segundo um escritório de auditoria ligado ao jornal Le Monde, tinham progredido em 9,5\% no primeiro semestre de 2011 para 46,2 bilhões de euros, com um número de negócios em alta de 6,6\% (650 bilhões de euros). Esperava-se que estes grandes grupos produzissem 94 bilhões de euros em 2011, em torno de 15\% mais do que em 2010. Quais são as razões desta divergência com a evolução "mediana" do PIB? Um crescimento que continuou na Ásia, uma racionalização "mundial" reforçada dos sistemas de produção, a busca de deslocalizações para países com baixo custo de mão de obra, múltiplas operações de fusão-aquisição intensificando esta estratégia de mundialização. Esta "racionalização" da produção só pode ser feita introduzindo-se novas tecnologias, ou seja, modos de produção mais "eficientes" (produtividade aumentada), de fato, reduzindo ainda, nestes setores, a parte do trabalho na produção. Estes ganhos de produtividade explicam por que não houve criações claras de empregos após os breves "saltos" conjunturais que aconteceram desde 2008 (crescimento sem emprego ou jobless recovery) e por que as admissões realizadas tiveram, frequentemente, condições salariais inferiores àquelas de antes da crise. 
Mas a "destruição" do capital não concerne apenas o setor "real" da economia, ela concerne, também, as "bolhas" de capital fictício acumulados, ao longo de fases recorrentes da especulação monetária e financeira. Evidentemente, é difícil apreender a amplitude destes processos permanentes de destruição de valor, mas o comportamento da Bolsa, muito volátil em períodos de crise, permite, no entanto, que se tenha uma ideia. Estimamos, assim, que em dois dias, 5 e 8 de agosto de 2011, na Europa e nos Estados Unidos, a capitalização da Bolsa tenha reduzido em mais de 900 bilhões de euros, sendo $37 \%$ de perdas dos seis meses precedentes, ao longo dos quais a única baixa dos mercados bolsistas tinha provocado a perda de 3,4 trilhões $^{13}$ de euros de capitalização bolsista dos dois lados do Atlântico (sendo quase um terço do Produto Interno Bruto dos Estados Unidos).

O setor bancário é um dos setores onde a "destruição" de capital fictício acumulado (gerador de confortáveis lucros na fase de ascensão do ciclo) é hoje a mais espetacular. Diante dos devedores quebrados (os Estados ditos "soberanos", mas também empresas em dificuldade), assistimos (ver acima) a uma brutal desvalorização de seus ativos. Eles precisam reduzir, drasticamente, seus balanços e almejam "recapitalizações" tão difíceis que os riscos de sua falência nunca foram tão próximos. Em consequência, a nova "purgação" almejada no setor em termos de emprego, na Europa, mas também nos Estados Unidos, surge como particularmente severa: mais de 6000 demissões no Unicredit na Itália, 4000 no Société Générale e 1400 no BNP na França, 50.000 nos bancos ingleses.

\section{DEFLAÇÃO DE PREÇOS, DE SALÁRIOSE DÍVIDAS PÚBLICAS COMO "SOLUÇÕES"}

Passado o tempo depois do começo da crise, podemos tentar fazer uma comparação com a

13 Aqui são levadas em conta as perdas de 500 empresas americanas do índice da Bolsa SP500 e as de 600 empresas europeias do DJ Stox 600. Estimativas da Dexia Securities, filial de corretagem do Banco Dexia (antes do seu desparecimento...).
Grande Depressão mundial dos anos 1930. Nos Estados Unidos, a chegada de F.D. Roosevelt ao poder, em 1933, corresponderá a uma relativa estabilização política depois de três anos de profunda crise. O padrão-ouro foi abandonado (desvalorização do dólar), uma lei de urgência para os bancos foi votada, bem como a lei para a recuperação da indústria nacional (National Industry Recovery Act), peça chave do New Deal. É uma forma de retorno ao "político" e ao Estado que, decerto, opera em detrimento de outros países europeus (e notadamente da Inglaterra), mas não se constitui menos como uma "ruptura" com a fase de deflação que tinha predominado desde o crash de Wall Street em 1929. ${ }^{14}$ Este adorno será relativamente efêmero, mas se traduzirá, no entanto, por uma recuperação parcial, até 1935-36, dos principais indicadores econômicos, em particular do desemprego.

Durante 2012, nada disso. Na Europa, não há nenhum sinal aparente - e no mundo também - de um retorno ao "político". Os cientistas políticos consideram, ao contrário, "que não há mais piloto no avião" e que, de fato, os Estados e as instituições internacionais parecem estar totalmente impotentes para controlar o endividamento dos Estados soberanos, para interromper a especulação, determinar as regulações que poderiam impedir a dominação sem partilha dos mercados. As causas desta situação estão ligadas, certamente, à mundialização das economias, à incapacidade de os Estados controlarem os movimentos de capitais; mas as razões fundamentais precisam ser encontradas na própria natureza do capitalismo e na maneira pela qual suas contradições se aprofundaram desde 2008.

Somos levados, aqui, à contradição fundamental, já explicitada entre o capital e o trabalho e às suas diversas expressões, dentre as quais, principalmente a partir de Marx, aos mecanismos de afetação da mais-valia produzida entre assalariados e capitalistas. Esta afetação não poderia se con-

\footnotetext{
14 Para uma visão mais apologética deste período, ver a obra clássica de A.M. Schlesinger Jr. (1971). Sobre este período e o seguinte, ver nossa contribuição no Congresso Marx International VI (2010).
} 
fundir com a abordagem "básica" fundada sobre “a partilha” do valor agregado. A razão é evidente: as variáveis tiradas da caixa de ferramentas da economia keynesiana não podem dar conta da relação salarial apreendida pela abordagem de Marx, muito mais complexa, porque integra, notadamente, a taxa de exploração da força de trabalho, bastante difícil de ser medida. O mesmo acontece com relação ao PIB (o Produto Interno Bruto considerado, na economia, como a soma dos Valores Agregados), já que ele só dá conta muito imperfeitamente da riqueza produzida e, notadamente, de sua natureza e de sua utilidade social. Para ilustrar este ponto, podemos lembrar que não é indiferente, de um ponto de vista social, produzir "manteiga ao invés de canhões", ou mesmo para o Estado, recrutar um soldado, ao invés de uma enfermeira. No entanto, do ponto de vista do PIB, o "valor" anexado a estas produções ou as "remunerações" das funções citadas são estritamente equivalentes. Na França, para tentar minorar esta carência, um grupo de trabalho "oficial" foi formado em 2009, presidido pelo Prêmio Nobel de Economia, Joseph Stiglitz. Mas os resultados são frágeis. Faz parte da própria essência do sistema tentar diminuir ao máximo a remuneração da força de trabalho, e a demanda de consumo global é sempre insuficiente com relação às capacidades de produção acumuladas e às potencialidades da produção (é preciso, aqui, tentar localizar no nível global, ultrapassando as abordagens do contexto restritivo dos Estados nacionais). Mas o que foi característico do período recente foi, nos países "centrais", a amplitude da "punção" operada pelo capital sobre a remuneração do trabalho. Todos os dados numéricos indicam que a "partilha" salários-lucros nunca foi, desde a guerra, tão desigual e isso com benefício dos detentores do capital. Com a extensão do desemprego, as desigualdades de renda no nível das famílias se ampliaram e as políticas fiscais liberais só fizeram agravar a situação.

Esta "purgação salarial", o desemprego, o agravamento das desigualdades pela distorção fiscal, poderiam ter constituído um fator de "retomada" da economia, já que oferecem, no fim das con- tas, condições de remuneração e de produção mais favoráveis para valorização do capital. Nada disso se passou e isso apesar da injeção intensiva de liquidez na economia. Este processo, identificável nos momentos iniciais pós-crise, perdurou e se ampliou nos Estados Unidos. Na Europa, a crise das dívidas soberanas conduziu os Estados a utilizar o mesmo método: primeiro para "salvar" os bancos, depois, acessoriamente, para contribuir com a "retomada" da economia e resolver, em certos países, as necessidades sociais mais urgentes. Em todos os lugares, os déficits e a dívida pública se aprofundaram ${ }^{15}$ consideravelmente.

É, portanto, esta criação maciça de moeda que contribuiu, em parte, apesar de todos os obstáculos, para a continuidade da valorização do capital. A consequência foi o aprofundamento, em grande escala, da dívida pública (ou dívida "soberana"). Como se opera este processo? Por um mecanismo bastante simples, bem descrito pelos economistas: as dívidas estão na origem das dívidas "particulares" geradas pelas ofertas de crédito de banqueiros privados (ver o exemplo dos créditos imobiliários nos Estados Unidos). Os bancos, inclusive ao emprestar às famílias com baixos rendimentos, encontram seu lucro nestas operações de empréstimo e se favorecem sem assegurar as garantias necessárias. Quando chega a crise, os bancos, depois de terem "titularizado" estas dívidas e "difundido" por todo o sistema, se voltam para o Estado (os cidadãos) e para os bancos centrais que devem, assim, recapitalizar as instituições hipotecárias e os bancos em risco de falência. Como? Através de "empréstimos" com taxas baixas $(0 \%$ na maioria das vezes), pela "monetização" das dívidas, ou seja, pela criação monetária. As dívidas são, assim, transferidas para os Estados que devem, a par-

${ }^{15} \mathrm{O}$ papel dos gastos militares é, infelizmente, na maior parte das vezes, "esquecido" (ou não especificado) no aprofundamento destes déficits. Vários think tanks americanos, conselheiros de Obama, tinham estabelecido, em meados de agosto de 2011, que a dívida pública dos Estados Unidos (que passou a 6,8 trilhões de dólares em 2001 a 14000 trilhões em 2011) tinha sido largamente alimentada pelos gastos militares do Pentágono para as guerras do Afeganistão e do Iraque. Com efeito, se ao custo dessas guerras, somássemos a luta antiterrorista, o total, para o decênio, teria resultado, de acordo com os anos, entre $40 \%$ e $50 \%$ de aumento da dívida pública. 
tir disso, garantir a carga (aprofundamento dos déficits orçamentários) e, portanto, voltar-se para os contribuintes. O fenômeno não é novo, decerto, e Marx, desde a época pré-industrial, já o considerava como uma das características do capitalismo moderno:

A dívida pública, isto é, a alienação do Estado seja despótico, constitucional ou republicano marcou com seu selo a era capitalista. A única parte da chamada riqueza nacional que entra realmente na posse coletiva dos povos modernos é a sua dívida pública [...] O crédito público, eis o credo do capital (Marx, 1977, p. 196).

Marx, em termos de uma atualidade surpreendente, indica como esta dívida pública opera como "um agente de acumulação", pois, ele diz, “com um passe de mágica, ela dota o dinheiro improdutivo de virtude reprodutiva e o converte em capital sem que tenha por isso de se submeter aos riscos, aos problemas inseparáveis de seu emprego industrial e mesmo da usura privada". ${ }^{16}$ Ele mostra bem, desde a origem, a conivência entre os bancos, "as associações de especuladores privados" e os governos, e ironiza o "efeito produzido nos contemporâneos pela aparição repentina desta horda de bancocratas, financiadores, rentistas, agentes imobiliários, agentes de câmbio, homens de negócios e linces" (op. cit, p. 197). O papel dos banqueiros de hoje, dos dirigentes de "hedge funds" e de agências de classificação de risco, traders e especuladores de todo gênero não é muito diferente e nos leva a "questionar" a própria natureza dos "mercados financeiros".

Uma das vantagens da abordagem da escola de Marx é que ela permite compreender as diferentes formas do valor e os diferentes tipos de capitais que são sua expressão: capital produtivo, capitaldinheiro, capital comercial, capital bancário, todos considerados como forma de existência particular de valor. Deste ponto de vista, os mercados "financeiros" não são "exteriores" ao Estado e ao sistema político, eles são organicamente ligados a ele. Partindo de uma problemática diferente e analisando

${ }^{16}$ Marx K. (1977). Livre I, Chap.31. Tome III, Editions Sociales, 1977, p. 196-198. as relações entre o "sistema financeiro" e "o sistema estatal”, Werrebrouck (2011) mostra bem que, na era da mundialização, o Estado tende a se "enquistar na finança”. Isso não significa o desaparecimento do "político", mas um funcionamento do Estado "sobre a base dos interesses superiores da finança". Isso implica, aliás, segundo ele, "uma troca de serviços entre os financiadores e os empreendedores políticos" com tudo o que isso pode implicar do ponto de vista dos "conflitos de interesses". O conflito de interesses na finança é, aliás, a sanção jurídica que permite despistar as violações da lei, o conluio ilegal entre os "políticos", os financiadores e... os fraudadores. ${ }^{17}$

Assistimos, então, na Europa, à emergência de uma nova categoria socioeconômica, já presente nos Estados Unidos, aquela dos "financiadoresfuncionários”. Enquanto que, até então, os antigos (altos) funcionários podiam "preguiçar" nos bancos privados (os funcionários-financiadores), a partir de então, os "financiadores" tomam lugar diretamente nas engrenagens do Estado e das instituições internacionais. ${ }^{18}$ Chegamos, assim, ao tríptico americano da "porta giratória" entre a FEDTesouro, Wall Street e a Casa Branca. Uma espécie de simbiose orgânica entre estas instituições com os mesmos protagonistas em funções intercambiáveis.

Uma vez que eles parecem ignorar a realidade, os discursos e proclamações sobre a necessidade de controlar, até de "domesticar" a finança e os mercados financeiros, de colocá-los "a serviço" do crescimento econômico só mostram ou irenismo ou pura mistificação. Propor que o Banco Central Europeu - BCE venha "salvar" os bancos, comprando-lhes seus títulos soberanos desvalorizados

17 Sobre este ponto, ver a recente obra de Jean-François Gayraud (2011). O autor, criminologista, mostra a dimensão criminógena da desregulação monetária e financeira, os enormes ganhos (ou perdas) ocasionados nos Estados Unidos e no mundo pela violação da lei.

${ }^{18}$ Um exemplo desta evolução nos é fornecido por três nomeações recentes: a de Loucas Papademos como Primeiro Ministro da Grécia, a de Mario Monti como Presidente do Conselho na Itália, a de Mario Draghi, como Presidente do Banco Central Europeu. Todos três são antigos dirigentes e conselheiros do Banco Americano Goldman Sachs, banco que "ajudou” a Grécia a maquiar suas contas. O trabalho prioritário deles consistia, então, em informar ao seu banco sobre os "negócios públicos europeus" e as políticas de taxa de juros dos Bancos Centrais. Roche Marc (2011), p. 2. 
revela a mesma ilusão. O BCE, assim como a União Europeia, é uma construção jurídica "pesada" que, desde sua origem, foi concebida para responder, no contexto europeu da mundialização, às necessidades do capitalismo internacional. A "democratização" de suas funções suporia questionar radicalmente seus princípios fundadores.

\section{A CONCORRÊNCIAEOS PREÇOS: a deflação ou a inflação comoúltimos recursos do capitalismo?}

A crise aberta das dívidas soberanas, iniciada pela situação da Grécia, mas prolongada, agora, na escala de toda a Europa, deve nos levar não a elaborar cenários hipotéticos de "saída da crise", mas a considerar a entrada em uma nova etapa da crise, certamente mais destrutiva ainda, aquela de uma deflação mundial. Esta deflação poderia, então, tomar, na ausência de uma transformação radical do regime político, uma forma tripla: uma deflaÇão dos preços, mas, também, uma deflação salarial, bem como uma deflação das dívidas. Quais são hoje os fundamentos teóricos de tal possibilidade?

Uma constatação, antes de tudo. O verão de 2011 e o novo crash da Bolsa em setembro-outubro parecem ter "jogado uma ducha fria” sobre as esperanças de todos os "especialistas" e instituições que tinham anteriormente previsto a retomada da economia mundial. O FMI publicou, no último dia 20 de setembro, novas previsões econômicas para o balanço de 2011 e 2012. Segundo estas previsões, o crescimento mundial cairia outra vez de 5,1\% para 4,0\% em 2011 e 2012, mas, para os países “avançados”, seja da zona do euro ou os Estados Unidos, o crescimento seria particularmente medíocre (+1,6\% em 2011 para a primeira; $+1,5 \%$ para os segundos). O Japão veria seu crescimento reduzir em 0,5\% em 2011 e, ainda, em 2,3\% em 2012. Somente a China conservaria um crescimento superior a 9\% e a Índia um crescimento superior a 7\%. Mas, desde esta publicação, a crise grega e aquela das dívidas soberanas europeias levaram os economistas a revisar, ainda mais para baixo, estas previsões. As Bolsas mundiais, já muito afetadas pelo crash de agosto-setembro, continuaram caindo.

No dia 23 de novembro, uma nova etapa foi transposta na separação do sistema de auxílio à Grécia e aos países endividados: uma parte dos títulos do Tesouro (39,0\%, sendo 2,4 bilhões de euros sobre 6 bilhões) emitidos pela Alemanha não puderam ser subscritos, uma proporção jamais atingida. Isso significa que a principal nação europeia, supostamente a mais potente economicamente, não escapa mais à desconfiança “dos mercados". Se, de um dia para o outro, a dívida alemã deveria, por sua vez, se converter em "ativo de risco”, exatamente como aquela da Grécia ou da Itália, é mesmo o conjunto da zona do euro que seria recolocado em questão.

Entramos, portanto, a partir disso, em uma fase onde a "saída da crise" não é nem sequer imaginada, nem mesmo imaginável a curto-médio prazo. Para além da continuidade e ampliação dos conflitos atuais, como o capitalismo tentará superar suas contradições e com que consequências sobre o plano político e social? Uma maneira puramente "econômica” de apreender a situação pode consistir em examinar a alternativa que será, necessariamente, colocada entre a inflação e a deflação, ficando entendido que, para o movimento social, os trabalhadores e os jovens, nenhuma destas soluções poderá permitir resolver os problemas de fundo colocados para a sociedade.

Para tentar ilustrar esta alternativa, é preciso que reexaminemos os mecanismos gerais da concorrência evocados anteriormente, pois eles nos permitirão levar em conta um elemento essencial do funcionamento da economia capitalista: $a$ determinação do nível geral dos preços. ${ }^{19} \mathrm{Na}$ econo-

${ }^{19}$ Ver em Marx que a análise dos preços e suas variações só são compreensíveis a partir da teoria do valor: "O preço, de acordo com seu conceito geral, é antes o valor sob forma de dinheiro" ou, ainda, "O preço, é o valor expresso em moeda”. O capital, Livro 3, Cap.10. "Por s mesmo, o preço não é outra coisa além da expressão monetária do valor": "Salário, preço, lucro", p.87, Ed. Sociales". Sobre as relações de valor-preco e o problema da "transformação", Andrew Kliman refutou, de modo muito convincente, as críticas feitas a Reclaiming Marx'Capital. A Refutation of the Myth of Inconsistency”, Lexington Books, 2007. 
mia capitalista, lembremos, os preços das mercadorias são determinados por seus preços de produção (custos de produção aos quais se acrescentam o lucro médio). Os mecanismos pelos quais o valor determina o preço das mercadorias (e dos serviços) são complexos, pois a composição orgânica entre os diferentes ramos da produção (e no próprio seio destes ramos), as condições técnicas de produção, evidentemente, não são homogêneas. Os preços de certas mercadorias podem, então, se afastar, notavelmente, do seu valor e certos capitalistas podem obter, notadamente em virtude de uma tecnologia mais eficiente, superlucros. A necessária correspondência entre valores e preços não é, portanto, sinônimo de equivalência. No entanto, admitiremos, facilmente, que as leis da concorrência, tendo em conta a mobilidade dos capitais, tendem, não somente a equalizar as taxas de lucro, mas, também, os preços sobre os mercados.

Com a crise aberta em 2008, já dissemos, as leis da concorrência se tornaram cada vez mais duras e podemos estimar que, "tudo igual, aliás", como sempre dizem os economistas, a pressão para reduzir os preços se acentuou. É preciso admitir que, de maneira geral, as pressões deflacionistas são concomitantes à crise. ${ }^{20}$ De fato, as tendências deflacionistas se fizeram sentir bem antes da "ruptura” de 2008. Além da longa deflação japonesa, destacamos, desde o início dos anos 2000, nos Estados Unidos e na Europa, uma redução da taxa de utilização das capacidades produtivas. Em vários setores, em particular aqueles que estão em contato com a demanda final (bens de consumo) ou com intermediários (bens de equipamento), constatamos uma superprodução recorrente. Isso resulta das supercapacidades que reduzem "o poder de mercado" das empresas, pressionando suas margens e impedindo o repasse dos custos sobre os preços da venda, empurrando para baixo o preço dos produtos. Essas pressões deflacionistas não concernem, todavia, ao setor dos produtos brutos e de energia. A deflação resultaria, assim, das leis

${ }^{20}$ Para a França, ver Aglietta M, Berrebi L. (2004). p. 15-16 da concorrência analisadas por Marx e da correspondência necessária entre valor e preço.

Embora, depois do final de 2008, tendências deflacionistas tenham se manifestado em diversos setores de atividade (automobilístico, têxtil e outros ramos de bens de consumo e de bens de equipamento), na maior parte dos países industriais - e isso até hoje -, o nível médio dos preços não baixou, continuou aumentando, embora de maneira bem mais reduzida e diferenciada. ${ }^{21}$ É, aliás, ao postular que os preços não poderiam realmente voltar a subir que o risco inflacionário foi, a partir disso, limitado, ou mesmo descartado e que os planos de "salvamento" dos bancos, pela criação maciça de moeda, tinham sido justificados e colocados em prática, na Europa, mas, sobretudo, nos Estados Unidos.

Estas concepções foram validadas, não somente por "especialistas" keynesianos ou póskeynesianos (Krugman), mas, também, por políticos e banqueiros perfeitamente ortodoxos (Bernanke nos Estados Unidos). A referência implícita era o temor de um retorno ao período sombrio da crise de 1929 até a eleição de Roosevelt em 1933, período no qual "a ortodoxia monetária" de redução da massa monetária tinha prevalecido. ${ }^{22}$ Lembremos que, nos Estados Unidos, entre 1929 e 1933, o produto nacional líquido com preços constantes tinha reduzido em mais de um terço, bem como o preço do bruto. O estoque de moeda diminuiu, também, em um terço entre 1929 e 1933 e os depósitos nos bancos em $42 \%$. Ao mesmo tempo, a renda monetária foi reduzida em 53\% (36\% em termos reais). No momento mais forte desta crise deflacionista, temos um desempregado para três ativos. De 1929 a 1932, a produção industrial mundial (exceto a União Soviética) reduziu em $37 \%$ e o volume do comercio internacional em $26 \%$.

${ }^{21}$ No lugar de índices gerais de preço (como o indicador INSEE), que só operam retrospectivamente, o diagnóstico da deflação pelos preços poderia ser feito, considerando-se a discrepância crescente entre as capacidades de produção e as ordens de encomenda. Em uma primeira fase da crise, pudemos estimar que, na França, a partir de meados de 2008, as encomendas tinham reduzido em quatro meses, em mais de $20 \%$. A "pressão" sobre os preços foi, portanto, intensa.

${ }^{22}$ Friedman M., Schwartz A. (1963). Cap. 7, p. 299 e 301. 
Poderíamos dizer que, no momento do desencadeamento da crise e até 2009-2010, os mecanismos potentes da concorrência pesaram em favor da redução dos preços mundiais das mercadorias e dos serviços, mas que, contrariando o processo, a "impressora de dinheiro" e as diversas fórmulas de quantitative easing permitiram conter o fenômeno. A situação se modificará, portanto, no fim do período, pois assistiremos a uma forte alta do preço das matérias-primas, agrícolas e industriais, bem como dos preços do petróleo. Causas "reais", segundo os especialistas (o clima, a raridade de certos produtos), mas, também, incontestavelmente, a especulação. Com efeito, os capitais que, não conseguindo mais se valorizar no imobiliário ou na finança, se dirigem para estes novos mercados, onde é possível obter, rapidamente, lucros importantes. O contexto político geral do Oriente Médio, bem como as revoluções árabes, favoreceu, igualmente, o fenômeno.

Paralelamente à deflação pelos preços, é preciso considerar os processos de deflação salarial (diminuição dos ganhos do trabalho) que estão associadas a ela. Teoricamente, mesmo se, em uma primeira etapa, notadamente em um país como a França, as modalidades de seguro-desemprego e os "amortizadores sociais" puderam frear a redução dos ganhos salariais, a crise, nem que seja pela extensão do desemprego, deve, necessariamente, combinar deflação dos preços e deflação salarial. Mas há um processo deflacionário, que se aliará à deflação dos preços e dos salários, e que se manifesta, geralmente, na primeira fase da crise, é o da deflação das dívidas. Com efeito, a crise "revela" o superendividamento das empresas, dos bancos e, também, das famílias. Em 1929, nos Estados Unidos, o endividamento precursor do crash tinha se desenvolvido, sobretudo, através da compra de ações de títulos da bolsa, títulos que foram, especialmente na primeira fase de alta da Bolsa, adquiridos por crédito nos bancos, mas, também, em instituições financeiras especializadas, ${ }^{23}$ que, aliás, falirão em massa

${ }^{23}$ Este processo foi bem descrito por J.K. Galbraith e também J. Schumpeter. no momento do crash de outubro de 1929.

Irving Fisher (inicialmente um banqueiro, mas cujo banco tinha falido em 1929) tinha teorizado, retrospectivamente, sobre este mecanismo específico de deflação. Segundo ele, se as ações atingiram, em 1929, uma cotação tão elevada, sem relação com a perda de rentabilidade da economia real, foi porque os bancos tinham comprometido capitais em "operações improdutivas sem esperança”. O laxismo monetário, "a indulgência" do controle geraram "bolhas", um frenesi especulativo financiado pelo endividamento no setor imobiliário e na Bolsa. Ele questionou a responsabilidade da Reserva Federal, de Wall Street e da administração de Washington na propagação dos excessos do crédito e da deflação pela dívida resultante.

Para explicar a passagem brutal do boom à depressão, Fisher partia da situação excessiva do superendividamento e explicitava o processo da seguinte maneira:

[...] temos, primeiro, uma liquidação das dívidas conduzindo a vendas "de perigo", uma contração dos depósitos bancários no compasso do reembolso dos empréstimos, uma redução do nível dos preços. Se esta baixa dos preços não for "aplacada" por um meio ou outro, ela resultará em uma redução ainda maior da riqueza acumulada conduzindo a falências e bancarrotas e a uma queda dos lucros. Teremos finalmente uma baixa da produção, do comércio e do emprego. A poupança aumentará, reduzindo a velocidade da circulação monetária. Perturbações serão produzidas sobre as taxas de juros com, em particular, uma baixa das taxas de juros nominais (Firsher, 1933).

Se aplicarmos as concepções de Fisher à situação atual, podemos considerar que a deflação pela dívida está presente desde a crise dos subprimes de 2008-2009 nos Estados Unidos. No momento da reviravolta do mercado habitacional, os devedores de baixa renda tiveram de suportar dívidas muitos superiores ao valor dos bens imobiliários comprados com crédito e que se tornaram invendáveis. Deflação de ativos, mas, também, deflação dos preços das habitações. Esta situação foi a de 12 milhões de famílias americanas. Uma forte "purgação" imobiliária, com as mesmas 
consequências (desabamento dos preços) aconteceu na Espanha, Irlanda e Grã-Bretanha.

Tendências deflacionistas "globais" se desenvolveram, também, em certos países como o Japão onde, no fim de novembro de 2011, o consumo das famílias tinha reduzido em $3,2 \%$ em um ano. O Japão, penalizado pela desaceleração da economia mundial e o encarecimento do iene, tornando mais caras suas exportações, sofre há quase três anos, um recuo geral de seus preços, desencorajando os investimentos e toda retomada da economia.

Os mecanismos gerais da concorrência, em um contexto de interdependência mundializada das economias, têm, portanto, como consequência lógica, a manutenção dos processos de deflação. Salvo uma ruptura política radical, recolocando em questão o modo de produção do próprio capitalismo, à "estagflação rastejante" atual (recessão acompanhada de uma alta moderada dos preços) deveria suceder, então, uma nova fase da crise, que se traduziria por uma deflação dos preços e dos salários. A deflação das dívidas parece já estar em curso através da desalavancagem, termo de especialista, descrevendo o processo de "purgação" e de explosão das bolhas especulativas acumuladas com as consequências decorrentes, notadamente no nível do emprego. É evidente que, a exemplo da Grande Depressão dos anos 1930 nos Estados Unidos (entre 1929 e 1933), a ocorrência de tal situação se traduziria por um agravamento considerável da situação econômica e social atual: novas falências de empresas e de bancos, aumento intenso do desemprego e da pobreza, novas compressões salariais.

Mas, vimos anteriormente, nos principais países capitalistas, e, em primeiro lugar, nos Estados Unidos, o aumento dos déficits orçamentários e a emissão intensiva de moeda retardaram até agora a ocorrência desta situação. O quantitative easing americano é o exemplo mais evidente disto. A “retomada pela impressora de dinheiro" (em realidade, pelo electronic bank keyboard credit, ou seja, o crédito obtido pela simples inscrição informática sobre as contas da FED e dos bancos) deve ser considerada como um meio provisório e temporário de escapar dos limites de va- lorização capital, mas isso se traduz, na ausência de investimentos "rentáveis", em uma dívida ainda maior. ${ }^{24}$ Todavia, para os adversários da "ortodoxia monetária”, este seria, no entanto, o caminho a ser seguido, etapa obrigatória em direção a um retorno do crescimento e do emprego. Mas, como lembra Michael Hudson, essas intervenções repetidas de quantitative easing desarticulam a economia global. ${ }^{25}$ Assim, nos Estados Unidos, o Federal Reserv inundou o mercado, o sistema bancário, de tanta liquidez que os títulos do Tesouro têm agora um rendimento inferior a $1 \%$. Os bancos japoneses viram a taxa de empréstimos sobre o iene cair para $0,25 \%$. O objetivo proclamado era de que os bancos poderiam, a partir disso, emprestar, com uma margem, às empresas e às famílias. De fato, não foi a economia que se beneficiou deste afluxo, mas os mercados de ativos financeiros, bem como os investimentos dos bancos em dívidas soberanas, supostamente sem risco. Joseph Stiglitz denunciou, em 2010, essas práticas enganosas e predadoras de empréstimos, a criação de um novo sistema centralizado nas mãos dos banqueiros e de responsáveis políticos a serviço deles. ${ }^{26}$

Diante de outros países, na ausência de um sistema monetário internacional crível, de uma moeda de referência internacional indiscutível, a política americana de quantitative easing se traduz, segundo Hudson, em uma verdadeira "agressão financeira”, baseada na especulação bancária e financeira internacional, e há, da parte do Secretario de Estado do Tesouro, Mr. Geithner, certa má fé em acusar a China de querer manter a

${ }^{24}$ Segundo a primeira auditoria da FED, publicada em julho de 2011, mas pouco difundida, parece que os "empréstimos" com taxa zero colocados à disposição da economia americana e dos bancos, americanos e estrangeiros, ultrapassaram, largamente, o montante dos "planos de retomada” de 2008 e 2009, já que avaliados em 16 trilhões de dólares. Este número é superior à dívida interna americana e ao PIB americano. Ver "The GAO Report on the Fed" [2011] e A.Grossman : "La generosidad sin precedentes de la Reserva Federal”. http:// Sinpermiso.org, Mexico. Completer a bibliografia.

${ }^{25}$ Hudson M. [2010]: "US Quantitative Easing is Fracturing the Global Economy”, Levy Economics Institute, Working Paper $n^{\circ} 639$, novembro.

${ }^{26}$ Stiglitz Calls for Jail Time for Corporate Crooks, Daily Finance, http://www.srph.it, 21 de outubro de 2010. 
subavaliação do yuan com relação ao dólar. Trata-se, ainda, no contexto da concorrência aumentada, em condições onde a hegemonia política e militar dos Estados Unidos é cada vez mais contestada, de utilizar-se a moeda, o dólar, como uma "arma” da guerra comercial entre os diferentes blocos.

Martin Wolf tinha colocado o problema nestes termos:

Os Estados Unidos querem inundar o resto do mundo [de liquidez] enquanto este mundo tenta "deflacionar" os Estados Unidos. Esse deve ganhar, pois dispõe de munições sem limites. O que está em questão são as condições às quais o mundo deveria se submeter: as mudanças que deveriam operar nas taxas de câmbio nominais e as políticas econômicas de cada país no mundo inteiro. ${ }^{27}$

Não é dar prova de pessimismo considerar que as contradições agora acumuladas no sistema capitalista mundial irão exacerbar as tensões no período futuro. Se o fim de 2011 foi dominado pela crise europeia (ameaça de explosão do euro), 2012 poderá recolocar, no primeiro plano, as dificuldades da economia americana. Diante da Europa em crise, os Estados Unidos pareceram estar, apesar da degradação de sua nota de crédito durante o verão (perto do triplo $\mathrm{A}$ ), relativamente abastados. Mas isso é só aparência e, nesse ano de eleição, jamais o país conheceu uma paralisia não forem mais subscritos pelos "investidores" estrangeiros e, em primeiro lugar, pelos chineses? Toda a crise de confiança - e o contexto político de um ano eleitoral se presta perfeitamente a isso - teria consequências imprevisíveis. Os Estados Unidos seriam, portanto, obrigados a utilizar, ainda, a "arma" do dólar e sua desvalorização. Certos especialistas previram que o ano 2012 poderia ver uma queda de $30 \%$ do dólar americano com relação às principais divisas mundiais. O que, em uma economia que importa o essencial de seus bens de consumo poderia se traduzir em uma queda do poder de compra das famílias americanas, em um contexto de inflação crescente.

Os procedimentos de "negociação internacional" Europa-Estados Unidos, notadamente depois dos fracassos repetidos das reuniões do Grupo dos 20 chegaram ao limite. Os Estados Unidos tentarão reafirmar sua posição no mundo, um pouco da maneira como Roosevelt tinha imposto, em 1933, durante a célebre Conferência de Londres, diante da Inglaterra e seus aliados, a desvalorização do dólar e uma política comercial mais restritiva. Esta política isolacionista tinha constituído as premissas de um protecionismo que favoreceu, a partir de 1937, a orientação da economia americana em direção à economia de guerra.

Nos próximos meses, os desenvolvimentos "conjunturais" da crise econômica mundial refletirão, necessariamente, a exacerbação das tensões e a concorrência aumentada entre as grandes potências: a China e os países asiáticos, os Estados Unidos, a Europa, incluindo certos países emergentes novos, com contradições sociais e políticas crescentes. Esta evolução será, também, pontuada por resurgimentos marcados de militarismo em diferentes partes do mundo. A economia de armamento (e a economia da "reconstrução" que está ligada a ela) não foi abordada neste texto, mas continua sendo, sobretudo neste ponto da evolução da crise mundial, um "mercado" privilegiado para o capital em busca de valorização. As evoluções tecnológicas do setor e a "profissionalização" da guerra apenas sublinham sua importância no plano econômico e geopolítico. 
Mesmo que a crise pareça ser, com frequência, em sua evolução futura, uma crise financeira, bancária, ou monetária, lembramos que ela é, antes, em suas origens e em sua própria dinâmica, uma crise de lucratividade e superacumulação. Há, no nível mundial, um excedente de capital disponível em busca de valorização e a mais-valia extraída do trabalho, portanto, o lucro decorrente, é insuficiente para assegurar a reprodução do sistema. Do ponto de vista do capital, a crise que se ampliou depois de 2008 surge antes como o meio para resolver esta contradição e, com efeito, há três anos, a "purgação" do sistema se mantém sem trégua: destruição de uma parte do capital acumulado, deslocamentos, busca de novas esferas de valorização, notadamente nos Bancos e na finança, "sequestro" das dívidas dos Estados, etc.

Certos economistas acreditaram ver neste processo de predação um elemento de renovação do sistema produtivo, gerador de valor e de novas riquezas futuras. Assim, para Schumpeter, a "destruição" é considerada como "criadora", pois suscetível de promover novas tecnologias (um novo paradigma tecnológico). Mas, se esta destruição é, com efeito, uma das condições do retorno à rentabilidade para as empresas “sobreviventes", ela também tem um caráter autodestrutivo, na medida em que ela opera em uma lógica da busca do lucro máximo, ou seja, reduzindo, ainda, a parte do trabalho e do assalariado na produção; de fato, os mesmos instrumentos da criação de valor. ${ }^{28}$ Esta é a razão pela qual nunca foi tão urgente recolocar em questão a lei do lucro, ou seja, o próprio capitalismo.

Recebido para publicação em 27 de novembro de 2012 Aceito em 15 de fevereiro de 2013

\section{REFERÊNCIAS}

AGLIETTA, M.; BERREBI L. Le risque déflationniste a t'il été trop rapidement écarté?, Expertises Groupama, n. 2, 2004.

FISCHER, Irving. The Debt-Deflation Theory of Great Depressions. In: The Works of Irving Fisher. v. 10, Barber Editions, 1933.

FRIEDMAN M.; SCHWARTZ A. A Monetary History of the United States", 1867-1960, Expertises Groupama, n. 2, 1963.

GAYRAUD, de Jean-François. La grande fraude. Crime, subprimes et crises financières. Paris: Odile Jacob, 2011.

HARMAN, Chris. Zombie Capitalism: Global Crisis and the Relevance of Marx. Londres: Booksmarks Publications, 2010.

HUDSON M. US Quantitative Easing is Fracturing the Global Economy. Levy Economics Institute, Working Paper n. 639, novembro, 2010.

KLIMAN,Andrew. The Failure of Capitalist Production. Underlying Causes of the Great Recession. Londres: Pluto Press, 2012.

. Reclaiming Marx'Capital. A Refutation of the Myth of Inconsistency. Lexington Books, 2007.

MADRICK, Jeff. Age of Greed. The Triumph of Finance and the Decline of America. 1970 to the Present. Knopf Éditeur, 2011.

ROCHE Marc. La franc-maçonnerie européenne de Goldman Sachs. Le Monde, 16 de Novembre de 2011, p.2.

MARX K. Le Capital, Livre I, Chap.31 . Tome III, Paris: Editions Sociales, 1977. Salário, preço, lucro. Paris: Ed. Sociales, 1976.

ROLLINAT, Robert. Les Etats-Unis du New Deal à l'économie de guerre: quelles leçons pour la crise d'aujourd'hui?. Université Paris Ouest-Nanterre, Congresso Marx International VI 22-25 de setembro de 2010.

La guerre des monnaies: une nouvelle étape de la crise capitaliste? http://www.preavis.org/brechenumerique/article2438.html, março 2011.

SCHLESINGER Jr, M. A. M. L'ère de Roosevelt, tome 2, L'avènement du New Deal, Denoël, 1971.

WERREBROUCK J.C. Réflexion sur le gigantisme financier, junho 2011. Disponível em: http://www.contreinfo.info

WOLF, Martin. Why America is going to win the global currency battle. Financial Times, Londres, 13 de outubro, 2010. 


\section{NEW PHASE IN THE WORLD ECONOMY AND THE EURO CRISIS: China, Europe and America}

\section{Robert Rollinot}

This text is about the deeply underlying causes of the crisis and its manifestations over the past five years, particularly regarding the intense competition, truly a "currency war." Beyond the "chronicle of events" of the crisis its financial and monetary dimensions, a crisis of "sovereign" debts, the Euro's future and its "afterlife" - the author seeks out the problematic that has hovered over this crisis since 2008. The guiding principle capable of grasping its process is still the analysis of real process, based on Marx's method and theory, through the evolution of "competitive" capitalism. The importance of competition and also its current tendency for intensification have been revealed New conditions of capital appreciation and profit-seeking have become evident in complex processes of destruction-creation of value, and they also illustrate the mechanisms linked to super-accumulation of capital to the resulting super-production of goods. Marx helps us understand that in order for capitalism to survive, it must keep "extorting" the surplus value, whatever the cost. It is an absolute imperative for it to reproduce, and today this gives it a brutal predatory character in all societal domains. La nouvelle histoire économique (1997).

\section{NOUVELLE PHASE DE L'ECONOMIE MONDIALE ET LA CRISE DE L'EURO: la Chine, l'Europe et l'Amérique}

\section{Robert Rollinat}

Ce texte c'est une réflexion sur les causes profondes de la crise et sur les formes qu'elle a prises pendant les cinq dernières années tout particulièrement en ce qui concerne à la gigantesque concurrence qui est devenu une véritable "guerre des monnaies ". Il s'agit en fait, par-delà de la "chronique des évènements "de la crise, - en particulier dans leur dimension financière et monétaire, crise des dettes " souveraines ", avenir et " survie " de l'euro - de rappeler dans quelle problématique cette crise s'est inscrite depuis 2008. Le fil conducteur capable de saisir son processus reste celui de l'analyse du processus réel basée sur la méthode et la théorie de Marx à travers l'évolution du capitalisme de " concurrence ". La crise " révèle " l'importance de la concurrence et le fait qui aujourd 'hui elle tend aussi à s'exacerber. Elle met donc en évidence les nouvelles conditions de valorisation du capital et de recherche du profit. Elle se traduit par des processus complexes et différenciés de " destruction-création "de valeur et illustre aussi les mécanismes liés à la " suracumulation " du capital, à la surproduction de marchandises (toujours relative) qui en découle. La référence à Marx nous aide à comprendre que pour survivre, le capitalisme doit continuer à tout prix à " extorquer "la plus-value pour réaliser le profit. C'est un impératif absolu pour le fonctionnement du système mais aussi pour sa reproduction. C'est ce qui aujourd'hui lui donne ce caractère prédateur et brutal, non seulement au niveau du travail et de l'emploi, mais dans tous les domaines de la vie sociale.

Mots-CuÉs: Capital. Travail. Finances. Destruction des valeurs. Crise mondiale.

Robert Rollinat - Professor Honorário da Universidade de Paris X e da Universidade d'Artois. Integrou o GREITD, Groupe de Recherche sur l'Etat, l'Internationalisation des Techniques et le Développement - do qual participam Pierre Salama, François Chesnais, dentre outros. Especializou-se na história econômica, financeira e bancária da América Latina sobre o que publicou artigo Neoliberalismo e dilemas da privatização bancária na América Latina no no livro História à deriva (1993). É analista crítico da "new economic history" no livro 